UDC 005:658.15

http://doi.org/10.21272/mmi.2019.2-03

JEL Classification: G32, G33

Grzegorz Zimon,

Ph.D., Rzeszow University of Technology, Poland

Halina Chlodnicka,

Ph.D., Rzeszow University of Technology, Poland

\title{
INNOVATION IN FINANCIAL REPORTING: THE ASPECT OF THE CAPITAL GROUP
}

Abstract. Enterprises operating in capital groups are made to create consolidated financial statements according to IFRS. In Poland, when trying to assess a financial situation based on consolidated financial statements, one may receive misleading information about a given capital group. In the capital group, there may be enterprises whose financial security is threatened and are close to bankruptcy and the consolidated financial statement presents the financial standing of the group as good. Is the current formula of the financial statements perfect, is it possible to improve it? The purpose of the article is to create an innovative formula of a financial report that will allow to easily and clearly assess the financial situation of enterprises belonging to capital groups. The new formula allows to clearly present the threats as well as the current situation of the business entity. The disclosure of possible threat symptoms may first of all be helpful to the unit, it will mobilize to descend from such positions, it will be possible to react to the deterioration of the assessment results, and it will be possible to find a shorter, faster way to find an investor. Even an investor who has such information can offer help himself. Information about symptoms is very important if something goes wrong, bankruptcy is not avoided despite hiding data, but it allows reliable assessment of the entity by owners, management and other recipients. The report of the new formula eliminates all financial instruments that are securities and their derivatives. The authors presented a proposal for changes only for the statement of financial position, but the changes should affect all parts of the report, which should be of interest to accounting officers. The innovative model of the new financial statements has been presented on the example of four Polish large enterprises. The methodology has been based on the national financial statements, as well as international guidelines and a proposal for changes. Statistical methods, financial indicators and comparison methods have been used. The financial data comes from the financial statements of the four Polish companies from 2016. The analysis of examples of large Polish enterprises showed that for the financial assessment and operational and financial safety, more information was provided by a new report form. Such a formula would also be very useful for unit reports.

Keywords: report, IRSF, capital group, innovation, investor.

Introduction. It has been known for centuries that international exchange is the prospect of economic development of enterprises. One can multiply arguments that decided about the fact that individual economies dared to leave the autarky phase, and thus joined the sphere of international exchange. As the main «in favour» one can cite the fact that international exchange paved the way for more efficient use of resources and productive forces in the scale of each country, and consequently on a global scale. The processes taking place are interrelated in domestic and international markets. Nowadays, the management of an economic entity often decides about combining business entities or joining an enterprise to a capital group. Mergers and acquisitions of enterprises appear more and more in the market, it is important that they do not lead to manipulation and speculation (Chlodnicka and Zimon, 2016). Managing a capital group requires the necessary experience and high qualifications. An integral element of the capital group documentation are the consolidated financial statements. The purpose of the article is to indicate innovative changes in the financial reporting of capital groups, which will present in a transparent way the effects of the entity activities and its financial situation.

Literature Review. Consolidated reporting, but not only reporting, still raises concerns among entrepreneurs and doubts as to whether the current reporting forms are not too complicated, or whether it is worth looking for new solutions. The data presented in the financial statements are not very legible

Cite as: Zimon, G., \& Chlodnicka, H. (2019) Innovation in Financial Reporting: the Aspect of the Capital Group. Marketing and Management of Innovations, 2, 33-41. http://doi.org/10.21272/mmi.2019.2-03 
for ordinary users and for many analysts «foggy» (Gotti, 2016). There are authors who believe that adopting IFRS raises the quality of accounting (Chen et.al., 2010) but there are also those who claim differently (Ahmed et.al., 2013). According to other, German GAAP standards are not worse (Van Tendello and Vanstraelen, 2005). Next theme of fair value, which is currently one of the most widely used measurement methodologies in IFRS1 accounting standards (Zamora-Ramirez and Morales-Diaz, 2018).Other authors have argued that IFRS are intended for consolidated accounts and for the needs of capital market investors, raising practical concerns about the relevance of IFRS for separate financial statements (European Financial Reporting Advisory Group, 2011) (Palea, 2014). Many authors, in turn, argued that the lower importance of the unitary financial statements may stem from their use for regulatory and tax purposes (Choi and Mueller, 1992; Delvaille et.al., 2005; Whittington, 2005). Unconsolidated bills are the starting point for tax calculations, although the degree of linkage between taxes and financial reporting varies between countries and time, depending on different purposes attributed to financial rapporteurs by the decision makers (Pfaff and Schroer, 1996). In turn, Callao, Jarne and Lainez (Callao et.al., 2007), for example, focus on the adoption of IFRS in Spain and state that the importance of financial reporting does not improve, and comparability is even worse for companies adopting IFRS. On the other hand, Horton and Serafim (Horton and Serafeim, 2010), when examining the British stock market, have discerned the decrease in forecast errors for companies that have been compelled to adopt IFRS. One can see that the subject of consolidated reports and the introduction of IFRS is a popular object for a discussion, analysis and research. Although this issue is often taken up in national and international publications, no novelty is introduced. Due to such needs, current solutions have been presented, especially in international solution proposals, and an attempt has been made to formulate a new formula for the financial statements.

Methodology and research methods. Research methodology has been based on the national financial statements, as well as international guidelines and a proposal for changes. Statistical methods and comparison methods have been used. The financial data comes from the financial statements of the four Polish companies from 2016. The outcome - an attempt to create a new formula of the statement of financial position, giving clear results of the assessment of the financial situation.

Results. Studies show that the institutional background of a country plays a role in the financial reporting standard setting (Navarro-Garcia and Bastida, 2010). Domestic accounting standards differ from IFRS more in code-law countries than in common-law countries (Ding et.al., 2007). In code law countries, there is a greater degree of insider owners, such as banks, who get their information directly from management or may even participate in decision-making through board membership (Hope, 2003). Similarly, Hope, Jin and Kang (Hope et.al., 2006) stated that code countries are more likely to adopt IFRS in order to improve investor protection. In each country, there are other legal provisions regarding the activities of companies that regulate in detail accounting issues and include obligatory financial statements. The publication in 1997 of the updated versions of IAS 1 introducing certain international financial statements (Table 1) was a breakthrough in financial reporting.

Table 1. Structure of the annual financial statements according to IAS 1 and the Accounting Act (presented in brackets)

\begin{tabular}{l}
\hline Financial Statements \\
- statement of financial position (balance sheet); \\
- statement of comprehensive income (profit and loss account); \\
- statement on changes in equity (statement of changes in equity (fund)); \\
- cash flow statement - IAS 7 (cash flow statement); \\
- additional information and explanations and introduction to the financial report; \\
- a report on the operations of the unit.
\end{tabular}

Sources: authors' own study.
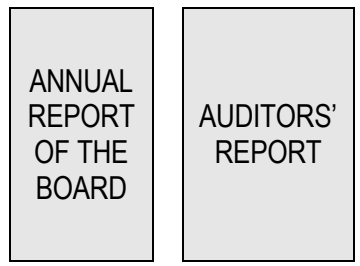
Financial statements should accurately reflect the financial position of the entity, its financial results and cash flows. Standards give quite general opportunities to present individual items, thus giving the freedom to create financial statements. Based on the type of business activity, each entity should determine whether in the statement of financial position the division into long-term (long-term) and shortterm (turnover) should be applied, but also such a division does not need to be done and the assets and liabilities are presented according to the liquidity criterion. On the other hand, in Polish law, such a division is imposed by the formalized balance sheet arrangement as an annexe to the Accounting Act. The IAS 1 solutions specify which main items should be shown, while the detail of the sub-classification depends on the IFRS requirements and the size and function of the amounts. Such a division should be disclosed in the statement of financial position or additional information. And also, in this case, national regulations - the Polish division imposes such a division. Another example of the generalization of the presentation of individual items is discontinuation, no obligation to present the result on operations. The basis for the functioning of IFRS regulations, however, are the conceptual assumptions being an integral part of the standards published by the IASB. They specify in detail the accounting principles that an entity should follow when preparing a report in accordance with IFRS. When conducting analyses and reflections on this topic the question raises whether to specify and provide as much information as possible, or aggregate positions, so that the information is short and transparent, or perhaps the results of the analysis of the financial condition of the surveyed units will prove similar. The answers to these questions are included in the article. The goal of the general-purpose financial report is to provide the public with detailed economic decisions, information about the financial position, results and cash flow of the entity. The modern order of the market economy and the constant need to make tough economic decisions connected with it causes a continuous increase in the requirements imposed on the content and quality of financial statements. The financial statement is intended to answer the following questions (does it provide such information in a present form?):

1. Is the business profitable?

2. Will the economic entity be able to continue it?

3. How did the entity generate and use inventory or cash resources?

4. Is it sufficient to quickly assess the situation of the individual?

5. What about the assessment of the risk of bankruptcy?

Nowadays, everything is complicated by fashion with actions taken as a part of external growth, which is mergers and acquisitions. In addition, along with economic, technological and social progress, the complexity of these links between business units is of increasing importance. Managing a capital group requires the necessary experience and high qualifications. An integral element of the capital group documentation are the consolidated financial statements. Creating consolidated documentation is difficult and time-consuming, but does it provide a lot of valuable information? Each company in the group maintains its accounting records and annually prepares its separate financial statements. The parent company prepares consolidated financial statements. There are six International Financial Reporting Standards for the preparation of consolidated financial statements. The consolidated statement reflects the economic content of the group as a single enterprise instead of the individual statements of a number of companies as separate legal entities. The requirement to prepare consolidated statements may obscure information about separate assets, liabilities and results of individual subsidiaries. The report may hide the situation in which one subsidiary generates losses, offset by the profits of other subsidiaries, or a situation in which one of the companies of the capital group has serious liquidity problems. Entities operating within the capital group have a chance to improve their liquidity and working capital by using mutual transactions. By using mutual transactions in a proper way, it is possible to help companies with negative working capital, i.e. the risk of losing 
financial liquidity (Zimon, 2018a; Zimon and Zimon, 2019). A dominating entity or any other entity operating within a capital group that has liquidity may help the enterprise in question (Zimon, 2018b).

Maybe it is worth considering any changes in this area. Should today's investors not receive information on what aspects of the business model have been unsuccessful or threatened by bankruptcy in previous years? Is this information supported by data about corrective steps taken by management? Should a corporation from the 21 st century not inform about its operations and economic conditions, systematically provide such strategic information, and not present how much was paid for buildings and machinery many years ago and manipulate individual reports to hide or improve the results, etc. (Lev and Feng, 2016). The world in most areas is subject to dynamic changes, and in the area of accounting, it seems to have been in place for decades. Only what is changing is the increasingly comprehensive financial statements. The US Steel Report of 1920 is a small, 40-page document, while its counterpart from 2012, in the best, consisted of 174 pages, which certainly obscured the information picture. In the report for 2012, there are a lot of different analyses, charts, financial data exhibits that adorn the report (Lev and Feng, 2016). The convergence project of US GAAP and IFRS is an attempt by IASB and FASAB to escape from the difficulty to accept the fact that the process of setting standards and introducing changes does not keep up with the changing reality offering access to information in real time. Author notice the fact that today's financial statements are quite extensive, therefore, the reader may have problems extracting relevant information (Surdykowska, 2010). The definitive effect of the standardization project should be to reduce the risk of making the wrong economic decisions. Consistency at the level of each row of the basic elements of the report opens new perspectives for analysing the company's activity (Gierusz, 2010). The principles of measurement and presentation of the statement of financial position (balance sheet) are presented in Table 2.

Table 2. An arrangement in the statement of the financial standing of the entity according to the

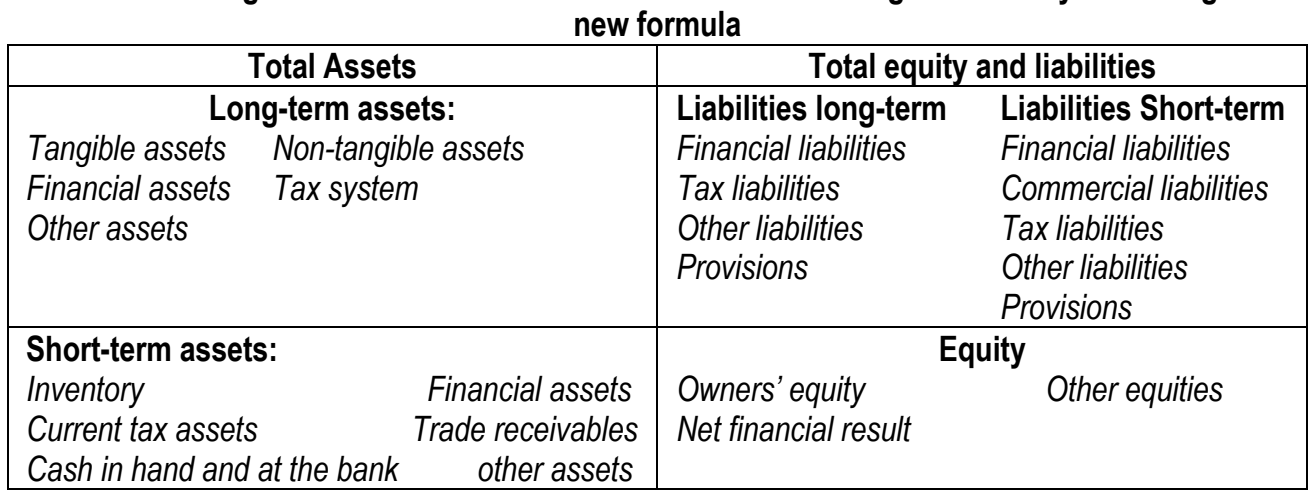

Sources: authors' own study based on (Walinska, 2013).

The aforementioned parts of the report already allow to give a bit more transparent information, but one can still strive for excellence. The more it seems as if the accountancy was in place, and everything is developing at a high pace. Investors need more expressive information, even if it is unfavourable but true. The statement of financial position should include information on overdue payments, interest, reserves, etc. - information that helped in the real assessment of the entity:

1. Unpaid overdue liabilities, receivables: commercial, for remuneration, towards public-law institutions.

2. Write-downs.

3. Provisions for pending cases with the probability of payment. 


\section{Interests.}

The authors suggest that the cost of interest is a proxy for the risk of company insolvency and is related to the company's credit rating (Ashbaugh-Skaife et. al., 2006). The items mentioned information about the threat to the activity, it can be called «symptoms of threat» and even «costs of bankruptcy». $\mathrm{H}$. Chlodnicka defined: «The costs of bankruptcy are decreasing economic benefits or spending during the reporting period in the future, by a unit of resources bringing these benefits to a credibly specified value, causing a deterioration of the financial standing of an economic entity, entailing the creation of additional burdens determining the future bankruptcy process» (Chlodnicka, 2014). The inclusion of detailed elements, their specification and valuation must refer to the overarching principles of accounting. Information on «bankruptcy costs» should also appear in the statement of financial position (balance sheet) but presented as symptoms of a threat and in the report on additional information and explanations. Such information should indicate the moment of appearance of such symptomatic threats, financial difficulties (Chlodnicka, 2004) and specify their size and comparison with the remaining data of current timely operations with a description of actions undertaken to reduce the symptoms of risk, bankruptcy costs or their elimination. This means that, unlike the previous regulation, the user of the financial statements will be able to assess the impact of the effects of this omission on the future income and financial position of the entity when deciding whether to discontinue the bankruptcy and initiate bankruptcy proceedings. Estimating these quantities can be labour-intensive. It requires a specific situation, i.e. an uncertain market position, which is why it would be best to measure these costs through separate records in its detail. Information on the costs of bankruptcy, symptoms of the threat would be useful for predicting the future, but also for the steps taken to improve the situation. Current reports are becoming more extensive, but they lack the simplest information. FASB issued 250 rules and footnotes (standards and updates), hundreds of pages. This regulatory avalanche causes longer and longer explanations in the footnotes to the financial statements (Lev and $\mathrm{Gu}, 2016$ ). These constantly raise doubts as to the clarity of the informative financial statements have led to attempts to build a new formula for the financial statements, supported by the examination of four entities and the calculation of indicators to assess these entities. It may turn out that the new formula would be simpler, containing the necessary information, and giving a reliable picture of the economic operator's situation without obfuscation with unnecessary information that is not much use for the potential investor. Table 3 presents the financial data of four Polish trading enterprises from 2016 in the new form of the report proposed by the authors.

Table 3. Information data in the report on financial standing

\begin{tabular}{|l|c|c|c|c|}
\hline ASSESTS & Company 1 & Company 2 & Company 3 & Company 4 \\
\hline \multicolumn{1}{|c|}{$\mathbf{1}$} & $\mathbf{2}$ & $\mathbf{3}$ & $\mathbf{4}$ & $\mathbf{5}$ \\
\hline Fixed assets including: & 1101661 & 8836160 & 8653547 & 1441215 \\
- company value & 19459252 & 35898786 & 36243093 & 58648051 \\
Current Assets & 11773085 & 17226855 & 16833280 & 36330021 \\
- Current inventories & 4598686 & 17822800 & 17048049 & 17791440 \\
- current receivable including: & & & & \\
1. From related entities & 2507726 & 656315 & 89589 & 578477 \\
- money on hand and on bank accounts & 579755 & 192816 & 926963 & 4398113 \\
- other assets & 0 & 0 & 0 & 0 \\
Symptoms of danger & 0 & 0 & 1345211 & 0 \\
- overdue stocks & 0 & 0 & 0 & 0 \\
- overdue receivables including: & & & & \\
- interest & \multicolumn{3}{|c}{} \\
\hline
\end{tabular}


Continue Tabl. 3

\begin{tabular}{|c|c|c|c|c|}
\hline 1 & 2 & 3 & 4 & 5 \\
\hline Total Assets & 20560913 & 44734946 & 44896639 & 60089266 \\
\hline \multicolumn{5}{|l|}{ LIABILITIES } \\
\hline Equity capital & 9513959 & 35286864 & 28755444 & 10877160 \\
\hline - basic & 264000 & 12100000 & 1800000 & 9049424 \\
\hline - other, including: & 8840845 & 18492356 & 23005174 & \\
\hline $\begin{array}{l}\text { - from the revaluation } \\
\text { - Net result: }\end{array}$ & & & & \\
\hline - of the current year, including: & 409075 & 4694508 & 3950270 & -1275124 \\
\hline $\begin{array}{l}\text { - the parent company } \\
\text { - subsidiaries }\end{array}$ & - & & & \\
\hline $\begin{array}{l}\text { - retained earnings } \\
\text { Non-controlling shares: }\end{array}$ & & & & 3102860 \\
\hline Liabilities & 9831886 & 7760071 & 9768642 & 31870779 \\
\hline - Current long-term liabilities & & & & 424407 \\
\hline - Current short-term liabilities & 9831886 & 7760071 & 9768642 & 31446372 \\
\hline 3. to related entities & & & & 243604 \\
\hline Symptoms of danger: & 1215068 & 1688011 & 6372553 & 17341327 \\
\hline - reserves & 563445 & & 1670149 & 1683892 \\
\hline - loans, overdue loans & & & 3631209 & 14801439 \\
\hline - overdue liabilities secured on assets & & & 0 & \\
\hline - wages not paid on time & & 305434 & 386092 & 365997 \\
\hline - overdue liabilities: & & & & \\
\hline - public law liabilities & 402789 & 1330182 & 598740 & 489999 \\
\hline $\begin{array}{l}\text { - other liabilities } \\
\text { - interest }\end{array}$ & 248834 & 52395 & 86363 & \\
\hline Total Liabilities & 20560913 & 44734946 & 44896639 & 60089266 \\
\hline
\end{tabular}

Sources: authors' own study.

Table 4 presents the reporting data by assigning it to the formula proposed by the authors of the article. Non-current assets are recognized in full, but at the recognition, they could be recognized with greater accuracy, they are items with high stability and durability, so their impact on the situation in individual years is of lesser importance. The report of the new formula eliminates all financial instruments that are securities and their derivatives. Such instruments have a varying degree of risk, so an investor does not need such information at the moment, because in a short time the situation may change significantly. The inclusion of such instruments may improve the overall picture of the entity, or even an improvement of ratios, but it is, in some cases, short-lived due to various influencing external factors. For such instruments, a new financial report should be created - «trading in financial instruments». The authors presented a proposal for changes only for the statement of financial position, but the changes should affect all parts of the report, which should be of interest to accounting officers. The proposed formula would not reveal short-term accruals, they are of little importance for the future. On the other hand, information on receivables or liabilities in settlements between related parties at the level of the consolidated statements would be very important. 
Table 4. Ratios applied to assess the financial standing

\begin{tabular}{|c|c|c|c|c|}
\hline Ratios & Company 1 & Company 2 & Company 3 & Company 4 \\
\hline$\frac{\text { Total liabilities }}{\text { Total assets }}$ & $\frac{11046954}{20560913}=54 \%$ & $\frac{9448082}{44734946}=21 \%$ & $\frac{16141195}{44896639}=34 \%$ & $\frac{49212106}{60089266}=82 \%$ \\
\hline$\frac{\text { Danger symptoms }}{\text { Total assets }}$ & $\frac{1215068}{20560913}=5 \%$ & $\frac{1688011}{44734946}=4 \%$ & $\frac{7717764}{44896639}=17 \%$ & $\begin{array}{l}\mathbf{1 7 3 4 1 3 2 7} \\
\mathbf{6 0 0 8 9 2 6 6} \\
=29 \%\end{array}$ \\
\hline$\frac{\text { Danger symptoms }}{\text { Total liabilities }}$ & $\begin{array}{l}\frac{1215068}{11046954} \\
=11 \% \\
\end{array}$ & $\frac{1688011}{9448082}=18 \%$ & $\frac{7717764}{16141195}=48 \%$ & $\begin{array}{l}\mathbf{1 7 3 4 1 3 2 7} \\
\mathbf{4 9 2 1 2 1 0 6} \\
=35 \%\end{array}$ \\
\hline$\frac{\text { Danger symptoms }}{\text { Current assets }}$ & $\frac{1215068}{19459252}=6 \%$ & $\frac{1688011}{35898786}=5 \%$ & $\frac{7717764}{36243093}=21 \%$ & $\begin{array}{l}\mathbf{1 7 3 4 1 3 2 7} \\
\mathbf{5 8 6 4 8 0 5 1} \\
=\mathbf{3 0} \%\end{array}$ \\
\hline$\frac{\text { Current assets }}{\text { Current liabilities }}$ & $\begin{array}{l}\frac{19459252}{9831886} \\
=1,98\end{array}$ & $\frac{35898786}{776071}=4,62$ & $\frac{36243093}{9768642}=3,71$ & $\begin{array}{l}586488051 \\
31870779 \\
=1,84\end{array}$ \\
\hline$\frac{\text { Net profits }}{\text { Equities }}$ & $\frac{409075}{9513959}=4 \%$ & $\frac{4694508}{35286864}=13 \%$ & $\frac{3950270}{28755444}=14 \%$ & $\begin{array}{l}-1275124 \\
10877160 \\
=-12 \%\end{array}$ \\
\hline$\frac{\text { Net profit }}{\text { Total assets }}$ & $\begin{array}{l}\frac{409075}{20560913} \\
=20 \% \\
\end{array}$ & $\frac{4694508}{44734946}=10 \%$ & $\frac{395027}{44896639}=0,9 \%$ & $\begin{array}{l}-1275124 \\
60089266 \\
=-21 \%\end{array}$ \\
\hline
\end{tabular}

Sources: authors' own study.

The stocks were divided into a group of overdue inventories, i.e. unsuccessful purchases, returns from customers. With this group of stocks, the company will have problems with the further sale, and at the moment they increase liquidity ratios. As presented in Table 2, it is possible to manipulate such settlements in the capital group to improve the financial situation, but at the level of consolidation, it cannot be seen. It is worth looking for new solutions and refining information that is powerful. The new formula was supported by assessing the situation of the surveyed entities using financial analysis. The following ratios were used to assess the financial standing of the surveyed entities, details are presented in Table 4. The new formula allows to clearly present the threats as well as the current situation of the business entity. The disclosure of possible threat symptoms may first of all be helpful to the unit, it will mobilize to descend from such positions, it will be possible to react to the deterioration of the assessment results, and it will be possible to find a shorter, faster way to find an investor. Information about symptoms is very important if something goes wrong, bankruptcy is not avoided despite hiding data, but it allows reliable assessment of the entity by owners, management and other recipients. Such a statement of financial position significantly improves current liquidity ratios because overdue items have been eliminated. This may raise doubts whether to settle arrears or current, if the ratios are high, they are mainly current, so that they do not become overdue with interest. Quite poor results are presented by the fourth entity, which belongs to the group, it may result that the subject in the group is not trying to get good results because the consolidated report will obscure everything anyway. The proposed proposal probably requires improvement, but it is worth considering only the skeleton of this part of the report. Professor Yuji ljiri in 1989 proposed a triple entry book, one of which did not arouse much interest among scientists. In addition to the current reports, he proposed a third report, similar to the momentum of the operation, informing about the pace of changes in the sales period, expenses and earnings. Two companies may have identical total sales in one quarter, but sales of one of them fell towards the quarter. Perhaps for investors, it would be important information about various change steps. It seems very important. Such a report would significantly increase investors' ability to predict future changes in 
corporate results. ljiri also proposed a detailed accounting procedure for measuring and reporting business dynamics. The triple accounting idea did not gain any attraction (Lev and Gu 2016, p. 7), and that is a pity.

Conclusions. Accounting needs changes, especially in the aspect of financial reporting. The main goal of the paper was to present an innovative formula of the financial report in the aspect of capital groups. The analysis carried out in the text of the article may help to make such an assessment. The proposed formula of this part as the basic one in financial reporting is short, clear, and it contains only the necessary up-to-date information. All items that are of no importance to the investor are omitted, but also entries at the level of the consolidated statements have been introduced, which have not been published so far. The analysis of examples of Polish enterprises showed that for the financial assessment and operational safety, more information was provided by a new report form. Such a formula would also be very useful for unit reports. The analysis shows that the report has not changed for decades except for minor cosmetic changes. It may be worth creating an additional part of the financial statements presenting the omitted information in the statement of financial position. Nowadays, many things are transferred to additional information and explanations, the volume of which is growing every year and who actually reads it.

Author Contributions: It is estimated that each of the four authors contributed $50 \%$ to the preparation of the article. The abstract was written by G. Z. and H. C. while introduction only by $\mathrm{H}$. C. Literature review was written by G.Z. and H.C. G. Z. and H. C conceived the study and were responsible for the design and development of the data analysis. Conclusions were presented by $\mathrm{H}$. $\mathrm{C}$. and G. Z. Methodology and the bibliography were prepared by all Authors.

\section{References}

Ahmed, S., Neel, M., Wang, D., (2013). Adoption of ifrs improve accounting quality? Preliminary evidence. Contemporary Accounting Research., 1344-1372.

Ashbaugh-Skaife, H., Collins, D., LaFond, R., (2006). The effects of corporate governance on firms' credit ratings. Journal of Accounting and Economics. 42, pp. 203-243.

Baik, B., Hyunkwon, C. Wooseok, C., Kwangjin, L., (2016). Who classifies interest payments as financing activities? An analysis of classification shifting in the statement of cash flows at the adoption of IFRS, Journal of Accounting and Public Policy. 35 (2016), pp. 331-351.

Callao, S., Jarne, J. I., Lainez, J. A. (2007). Adoption of IFRS in Spain: Effect on the comparability and relevance of financial reporting. Journal of International Accounting, Auditing and Taxation, 16(2), pp. 148-178.

Chen, H., Tang, Q., Jiang, Y., Lin, Z., (2010). The role of international financial reporting standards in accounting quality: evidence from the European Union. Journal of International Financial Management and Accounting. 21, pp. 220-228

Chlodnicka H., (2014). Sprawozdanie finansowe a pomiar efektow dzialalnosci przedsiębiorstwa w zagrożeniu kontynuacji dzialania, Uniwersytet Ekonomiczny we Wroclawiu, Wroclaw 2014, pp.87-101.

Chlodnicka H., (2004). Identyfikacja i systematyka kosztow upadlosci. [w:] Nowak E. (red.), Modele rachunku kosztow i rachunkowosci zarządczej. Wroclaw: Prace Naukowe Akademii Ekonomicznej we Wroclawiu, pp.18-31.

Chlodnicka H., Zimon G., (2017). Financial Situation Assessment Dilemmas of Selected Capital Groups, Central European Conference in Finance and Economics, Herlany, Slovak Republic, pp. 309-318.

Choi, F. D. S., Mueller, G. G. (1992). International accounting. Englewood Cliffs, NJ: Prentice-Hall.

Delvaille, P., Ebbers, G., Saccon, C. (2005). International financial reporting convergence: Evidence from three continental European countries. Accountingin Europe, 2(1), pp. 137-164

Ding, Y., Hope, O.-K., Jeanjean, T., Stolowy, H. (2007). Differences between domestic accounting standards and IAS: Measurement, determinant and implications. Journal of Accounting and Public Policy, 26(1), pp. 1-38.

Gierusz, J., Ocena przygotowanego przez IASB i FASB projektu sprawozdania finansowego, Zeszyty Teoretyczne Rachunkowosci, vol. 56 (112), Warszawa 2010, pp. 53-56

Gotti, G. (2016), Discussion of Segment Disclosure Quantity and Quality under IFRS 8: Determinants and the Effect of Financial Analysts Earnings Forecast Errors, The International Journal of Accounting 51 (2016), pp. 462-463.

Hope, O.-K. (2003). Firm-level disclosures and the relative roles of culture and legal origin. Journal of International Financial Management and Accounting, 14(3), pp. 218-248.

Hope, O.-K., Jin, J., \& Kang, T. (2006). Empirical evidence on jurisdictions that adopt IFRS. Journal of International Accounting Research, 5(2), pp. 1-20. 
Horton, J., Serafeim, G. (2010). Market reaction to and valuation of IFRS reconciliation adjustments: First evidence from the UK. Review of Accounting Studies, 15(4), pp. 725-751.

Lev, B., Gu, F., (2016). The End of Accounting and the Path Forward for Investors and Managers, New Jersey, John Willey end Sons

Lee, L., (2012). Incentives to inflate reported cash from operations using classification and timing. European Accounting Reiew. 87, pp. 1-33.

Navarro-Garcia, Bastida, (2010). An empirical insight on Spanish listed companies' perceptions of International Financial Reporting Standards, Journal of International Accounting, Auditing and Taxation 19 (2010), pp. 110-120

Palea, V., (2014). TaxationAre IFRS value-relevant for separate financial statements? Evidence from the Italian stock market, Journal of International Accounting, Auditing and Taxation 23 (2014), pp. 1-17

Pfaff, D., Schroer, T. (1996). The relationship between financial and tax accounting in Germany: The authoritativeness and reverse authoritativenessprinciple. European Accounting Review, 5(1), pp. $963-979$

Zamora-Ramirez, C., Morales-Diaz, J., (2018). The use of fair value mesaurement in financial raporting: A literature review. Estudios de Economia Aplicada, volume 36-2, May 2018, pp. 489-514.

Surdykowska, T., Perspektywy rozwoju rachunkowosci międzynarodowej, [in:] Zeszyty Teoretyczne Rachunkowosci, vol. 56 (112) Warszawa 2010, p. 145

Walinska E., (2013). Przychody rozliczane w czasie w swietle koncepcji wyniku calosciowego, [in:] A.Karmanska A. (ed.) Nauka o rachunkowosci na progu gospodarki opartej na wiedzy, Warszawa 2013, pp. 653-660.

Whittington, G. (2005). The adoption of international standards in the European Union. European Accounting Review, 14(1), pp. $127-153$.

Van Tendeloo, B., Vanstraelen, A., (2005). Earnings management under German GAAP versus IFRS. European Accounting Reiew. 14, pp. 155-180.

Zimon, G., (2018a). Oranization of transport in a commercial enterprise operating in a branch purchasing group. Estudios de Economia Aplicada, volume 36-3, Septiembre 2018, pp. 811-823.

Zimon, G., (2018b). Influence of group purchasing organizations on financial situation of Polish SMEs, Oeconomia Copernicana, vol. 9(1), 2018, pp.87-104.

Zimon, G., Zimon, D., (2019). An assessment of the influence of Nominalized Quality Management Systems on the Level of Receivables in Enterprises Operating in Branch Group Purchasing Organizations, Quality Access To Success, Volume: 20 Issue: 169, 2019, pp.47-51.

Грегоргз Зімон, Ph.D., Технологічний університет Жешува (Польща);

Галина Члодніка, Ph.D., Технологічний університет Жешува (Польща).

Інновації у фінансовій звітності: особливості фінансових груп

Компанії, що входять до фрінансових груп, формують єдину консолідовану фінансову звітність у відповідності до Міжнародної системи фрінансової звітності (МСФЗ). При иьому автори зазначають, що у Польщі оцінка фрінансового стану на основі наявної консолідованої фрінансової звітності інколи є не можливою або їі результати щодо ефективності функціонування певної фрінансової групи є дезорієнтуючими. Так, до фрінансових груп можуть входити компанії, фрінансовий стан яких знаходиться під загрозою банкрутства, однак, їх консолідована фрінансова звітність відображає надійний фрінансовий стан групи. Метою статті $є$ визначення напрямів удосконалення фінансової звітності з метою фрормування базису для адекватної оцінки фрінансового стану компанії. Запропонована авторами форма фрінансової звітності дозволяє виявити загрози, а також оцінити поточну ситуацію суб'єкта підприємницької діяльності. У свою чергу, виявлення можливих ознак появи загроз має ряд переваг, у першу чергу, для компанії. Так, своєчасне виявлення можливих загроз забезпечує швидке реагування на визначені проблеми з метою їх мінімізації, що призведе до підвищення рівня транспарентності фрункціонування фрінансових груп для інвесторів. Окрім цього, звіт за запропонованою фрормою включає звітність за цінними паперами та деривативами. Вихідні данні для дослідження сформовано на основі аналізу чотирьох великих компаній Польщі за 2016 рік. Методологію дослідження засновано на національних фінансових звітах, а також міжнародних рекомендаціях та пропозиціях для змін. Практичну реалізацію всіх етапів дослідження здійснено з використанням статистичних методів, фрінансових показників та методів порівняння. Результати аналізу досліджуваних компаній свідчать про те, що використання запропонованої формули фрормування фрінансової звітності генерує більш об'єктивну, адекватну інфоормаційну базу для оцінки фінансового стану компаній у порівнянні з діючою системою фрінансової звітності у Польщі.

Ключові слова: звіт, МСФЗ, фінансова група, інновації, інвестор.

Manuscript received: 11.04.2019.

(C) The author(s) 2019. This article is published with open access at Sumy State University. 